\title{
Effect of meteorological factors on Culex mosquitoes in Singapore: a time series analysis
}

\author{
Annabel Seah ${ }^{1}$ (D) Joel Aik ${ }^{1,2} \cdot$ Lee-Ching $\mathrm{Ng}^{1}$ \\ Received: 25 June 2020 / Revised: 6 October 2020 / Accepted: 20 November 2020 / Published online: 10 January 2021 \\ (C) The Author(s) 2021
}

\begin{abstract}
Culex mosquitoes transmit West Nile virus (WNV). We examined the weather dependence of adult Culex activity. Maximum temperature and absolute humidity were positively associated with adult Culex activity. Our findings support the use of weather data in timing WNV vector control measures.
\end{abstract}

Keywords Culex $\cdot$ Weather $\cdot$ Climate change

The Culex mosquito is a vector of the West Nile virus (WNV) (Paz \& Semenza, 2013). Migratory birds which are viral reservoirs travel along the East Asia Australasian Flyway, through WNV-endemic USA, before stopping over in Singapore (Yap et al. 2019), and may import WNV. Elevated global temperatures, as a result of climate change, accelerate mosquito development, thus resulting in changes in the transmission pattern of Culex transmitted viruses (Paz and Semenza 2013). While other studies have examined the effect of short-term climate variations on the adult Culex population in temperate (Paz and Semenza 2013), continental (Karki et al. 2016) and subtropical (Rueda et al. 1990) climate settings, this has not been investigated in the tropics.

We obtained data on ambient temperature, cumulative rainfall and absolute humidity ( $\mathrm{AH}$ ) from weather stations located across Singapore. We examined the short-term impact of these climate conditions on the adult Culex index, using data

Joel Aik

joel_aik@nea.gov.sg

Annabel Seah

annabel_seah@nea.gov.sg

Lee-Ching Ng

ng_lee_ching@nea.gov.sg

1 Environmental Health Institute, National Environment Agency, 40 Scotts Road, Environment Building, \#13-00, Singapore 228231, Singapore

2 School of Public Health and Community Medicine, Faculty of Medicine, University of New South Wales, Kensington, New South Wales, Australia obtained from the national Gravitrap surveillance program (Lee et al. 2013) on the rate of trapped adult female Culex quinquefasciatus - the most common Culex species in Singapore - which is defined as

Culex index $=\frac{\text { Total number of adult female mosquitoes }}{\text { Total number of Gravitraps }}$

from epidemiologic week (E-week) 44 of 2017 to E-week 7 of 2020.

Since the Culex mosquito lifecycle duration (7-10 days) (Centers for Disease Control and Prevention 2019) and adult lifespan (18-23 days) (Andreadis et al. 2014) total to 2533 days or around 5 weeks at maximum, we included immediate and delayed effects of all climatological variations up to this duration. This was similar to the lag duration reported in another study (Karki et al. 2016). We used a distributed lag non-linear model in the "dlnm" package (version 2.3.9) in R software (version 3.5.2) to account for delayed, non-linear effects of weather on adult Culex index, $Y_{t}$ in week $t$, as shown in Eq. 1:

$\mu_{t}=\beta_{0}+n s(t, d f)+S\left(x_{j, t}, \varphi_{j}, \tau\right)+\beta_{1} \sum_{l=1}^{l=L} \operatorname{res}_{l}$

where $\mu_{t}$ is the expected adult Culex index in week $t$ and $\beta_{0}$ represents the intercept. We accounted for trend and seasonality in $Y_{t}$ using natural cubic splines ( $\left.n s, d f\right)$, with $4 d f$ (degrees of freedom) per year. $n s$ functions with $3 d f$ are used to describe the smoothed $S\left(x_{j, t}, \varphi_{j}, \tau\right)$ relationship between $\mu_{t}$ and "cross-basis" matrices of each weather variable, $x_{j}$, for up to $\tau=5$-week lag respectively. Coefficient vector $\varphi_{j}$ represents 

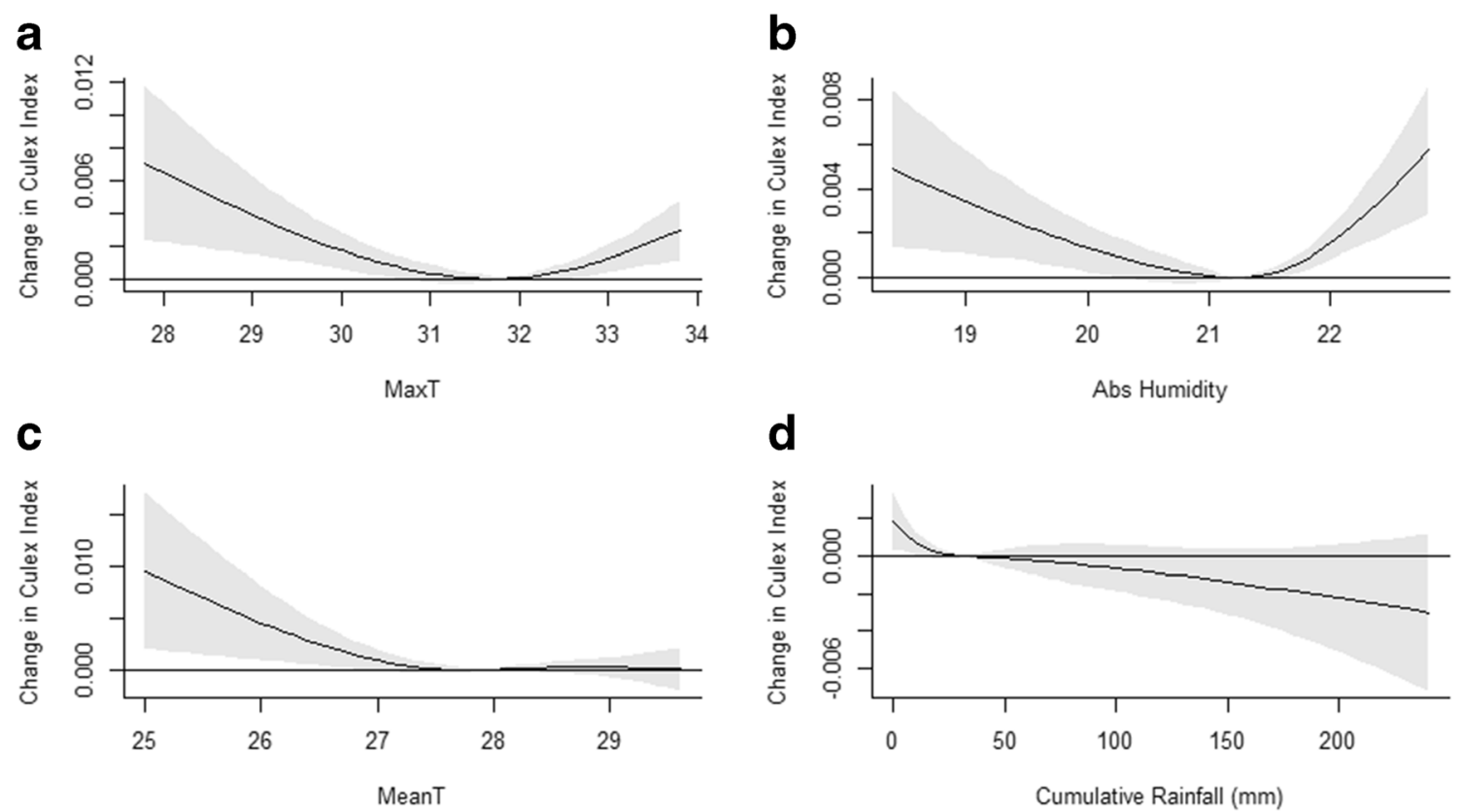

Fig. 1 Exposure-response curve showing overall cumulative effect on adult Culex activity. Overall cumulative effect of weekly a MaxT, mean-centred at $31.8{ }^{\circ} \mathrm{C} ; \mathbf{b}$ absolute humidity mean-centred at $21.2 \mathrm{~g} /$

changes in adult Culex index for a unit change in $x_{j}$ weather parameter. We added lags of deviance residuals res $s_{l}$ to account for serial correlation.

The U-shaped non-linear associations between the change in adult Culex index and MaxT demonstrate a less pronounced increase in adult Culex index as MaxT increases up to $30.5^{\circ} \mathrm{C}$ but becomes more pronounced as MaxT increases beyond $31.9^{\circ} \mathrm{C}$ (Fig. 1a). Increasing temperature accelerates larvae development, leading to subsequent increases in adult Culex abundance. However, this increase in adult Culex abundance plateaus at higher MaxT as increased thermal stress reduces adult survival. At higher MaxT threshold, another biological mechanism may be predominant. In Singapore, dry weather with higher temperatures are associated with excessive leaf shedding, resulting in a leaf litter build-up in drains (Ee 2014). Upon decomposition, the leaf litter habitat provides organic nutrients for the mosquito larvae (Noori et al. 2015), resulting in increased mosquito abundance.

Similarly, the increase in adult Culex index becomes less pronounced as AH increases up to $20.2 \mathrm{~g} / \mathrm{m}^{3}$ but becomes more pronounced as AH increases beyond $21.2 \mathrm{~g} / \mathrm{m}^{3}$ (Fig. 1b). We found the correlation between MaxT and AH to be weak and statistically insignificant $(r=0.064, p=0.489)$. Therefore, despite having similar U-shaped linear association as MaxT, the association observed between $\mathrm{AH}$ and adult Culex index is independent of MaxT. Instead, it could be due to an interplay of less shedding of dry leaves at lower $\mathrm{AH}$ levels, resulting in reduced availability of viable breeding

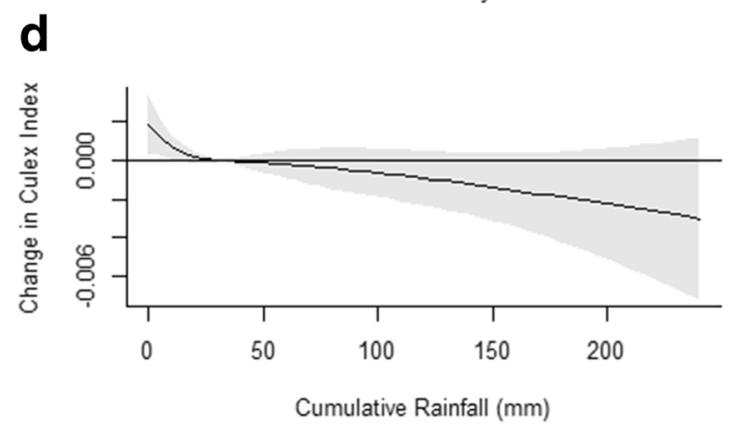

$\mathrm{m}^{3}, \mathbf{c}$ MeanT, mean-centred at $27.9^{\circ} \mathrm{C}$; and $\mathbf{d}$ cumulative rainfall, meancentred at $32.1 \mathrm{~mm}$. Shaded grey areas indicate $95 \%$ confidence intervals (CIs)

sites, but increased adult mosquito survival at higher $\mathrm{AH}$ thresholds as the higher atmospheric moisture content reduces egg and adult desiccation stress (Benoit et al. 2010).

The increase in adult Culex index becomes less pronounced as mean temperature increases up to $26.8{ }^{\circ} \mathrm{C}-$ similar to the results obtained for MaxT of this temperature range (Fig. 1c). Rainfall was negatively associated with the adult Culex index (Fig. 1d). While this relationship was statistically insignificant, it is consistent with other studies (Karki et al. 2016; Paz and Semenza 2013) and is plausible as heavy rainfall flushes Culex larvae from their unsheltered habitats (Karki et al. 2016), resulting in reduced survival to adulthood.

Our study provides evidence to support the relationship between short-term weather variations and adult Culex activity. With global warming, hotter and more humid weeks favouring adult Culex activity may be expected. Public health authorities seeking to reduce the risk of WNV transmission in tropical urban settings could time their vector control measures in anticipation of weather driven increases in adult Culex activity.

Supplementary Information The online version contains supplementary material available at https://doi.org/10.1007/s00484-020-02059-9.

Acknowledgements We thank the Meteorological Services Singapore (MSS) and the Environmental Public Health Operations Department (EPHOD) of the NEA for providing the weather and Culex data respectively for our study. 
Code availability Not applicable.

Authors' contributions AS and JA conceptualised the study, led the writing of the article, developed the analytic plan, analysed the data and interpreted it.

LCN provided feedback on data analysis and contributed to the interpretation of results and revising drafts of the article.

Data availability The weather data presented in this study are available upon reasonable request from the Meteorological Services Singapore (MSS) of the NEA (email: Contact_NEA@ nea.gov.sg). The Culex data presented in this study are available upon reasonable request from the Environmental Public Health Operations Department (EPHOD) of the NEA (email: Contact_NEA@nea.gov.sg).

\section{Compliance with ethical standards}

Conflict of interest The authors declare they have conflict of interest.

Consent to participate Not applicable.

Consent to publish Not applicable.

Abbreviations WNV, West Nile virus; AH, Absolute humidity; MeanT, Mean temperature; MaxT, Maximum temperature

Open Access This article is licensed under a Creative Commons Attribution 4.0 International License, which permits use, sharing, adaptation, distribution and reproduction in any medium or format, as long as you give appropriate credit to the original author(s) and the source, provide a link to the Creative Commons licence, and indicate if changes were made. The images or other third party material in this article are included in the article's Creative Commons licence, unless indicated otherwise in a credit line to the material. If material is not included in the article's Creative Commons licence and your intended use is not permitted by statutory regulation or exceeds the permitted use, you will need to obtain permission directly from the copyright holder. To view a copy of this licence, visit http://creativecommons.org/licenses/by/4.0/.

\section{References}

Andreadis SS, Dimotsiou OC, Savopoulou-Soultani M (2014) Variation in adult longevity of Culex pipiens f. pipiens, vector of the West Nile Virus. Parasitol Res 113(11):4315-4319. https://doi.org/10.1007/ s00436-014-4152-x

Benoit JB, Lopez-Martinez G, Phillips ZP, Patrick KR, Denlinger DL (2010) Heat shock proteins contribute to mosquito dehydration tolerance. J Insect Physiol 56(2):151-156. https://doi.org/10.1016/j. jinsphys.2009.09.012

Centers for Disease Control and Prevention. (December 3, 2019). Mosquito life cycle: Culex pipiens, $\mathrm{Cx}$. quinquefasciatus, and $\mathrm{Cx}$. tarsalis. Retrieved from https://www.cdc.gov/westnile/resources/ pdfs/FS_MosquitoLifeCycle-508.pdf

Ee, D. (2014, 7 May). Dry spell in Singapore fills streets, pavements and drains with more fallen leaves than usual. The Straits Times. Retrieved from https://www.straitstimes.com/singapore/dry-spellin-singapore-fills-streets-pavements-and-drains-with-more-fallenleaves-than

Karki S, Hamer GL, Anderson TK, Goldberg TL, Kitron UD, Krebs BL, Walker ED, Ruiz MO (2016) Effect of trapping methods, weather, and landscape on estimates of the Culex vector mosquito abundance. Environ Health Insights 10:93-103. https://doi.org/10.4137/ EHI.S33384

Lee C, Vythilingam I, Chong CS, Abdul Razak MA, Tan CH, Liew C, Pok KY, Ng LC (2013) Gravitraps for management of dengue clusters in Singapore. Am J Trop Med Hyg 88(5):888-892. https://doi. org/10.4269/ajtmh.12-0329

Noori N, Lockaby BG, Kalin L (2015) Larval development of Culex quinquefasciatus in water with low to moderate. J Vector Ecol 40(2):208-220. https://doi.org/10.1111/jvec. 12156

Paz S, Semenza JC (2013) Environmental drivers of West Nile fever epidemiology in Europe and Western Asia-a review. Int J Environ Res Public Health 10(8):3543-3562. https://doi.org/10.3390/ ijerph10083543

Rueda LM, Patel KJ, Axtell RC, Stinner RE (1990) Temperaturedependent development and survival rates of Culex quinquefasciatus and Aedes aegypti (Diptera: Culicidae). J Med Entomol 27(5):892-898. https://doi.org/10.1093/jmedent/27.5.892

Yap G, Lim XF, Chan S, How CB, Humaidi M, Yeo G, Mailepessov D, Kong M, Lai YL, Okumura C, Ng LC (2019) Serological evidence of continued Japanese encephalitis virus transmission in Singapore nearly three decades after end of pig farming. Parasit Vectors 12(1): 244. https://doi.org/10.1186/s13071-019-3501-0

Publisher's note Springer Nature remains neutral with regard to jurisdictional claims in published maps and institutional affiliations. 